\title{
1 Paideias and programs for Theology Without Walls
}

\author{
Robert Cummings Neville
}

Editor Jerry L. Martin asked me to explain how I became the kind of theologian without walls that I am. The first thing to say about that is that there are many kinds of theologians without walls, not just mine. Many different starting points exist, and there are many different kinds of theological problems in which to be interested. I myself am a systematic philosophical theologian, and I take myself to be accountable to any thinker in any tradition, religious or secular, who has an interest in the outcome of my inquiry. My inquiry has a number of parts, and at the beginning of my career I could not develop any of them very well. But I kept working on them all together and gradually became more sophisticated. It would be great to be deeply and evenly sophisticated, although I do not expect that! Here are some of the parts of my systematic philosophical inquiry. Note that this is the first time I have been asked to write in an avuncular voice: if I wobble between braggadocio and patronizing, remember it is a first attempt.

\section{Knowledge of religion}

I was born in 1939 in St. Louis, Missouri, and raised there through public schools until I left for college in $1956 .{ }^{1}$ My family was active in a rather liberal Methodist church. Most of our neighbors and my classmates were Roman Catholic; the more established German and Irish Catholics were resentful of the newly arrived Italians. When I was about 14, I edited our congregation's weekly newsletter and decided to write a series of 500-word columns about world religions. Based on encyclopedia articles, my columns dealt sequentially with Buddhism, Confucianism, Christianity, Daoism, Judaism, Hinduism, and Islam (in alphabetical order). This was not high scholarship and certainly had no peer review. Notice that Christianity was presented as one religion among many. No one gave me any grief for that. I'm proud that my first "publications" were about world religions.

In college I roomed with a Greek Orthodox and a Jew, never having met representatives of those religions before (my St. Louis neighborhood was rather homogeneous). I majored in philosophy, but we studied only Western philosophy, no Indian, Chinese, or Islamic. Not until I was teaching 


\section{Robert Cummings Neville}

at Fordham University did I begin to study non-Western philosophies and religions, under the prodding of Thomas Berry. He taught me Sanskrit and arranged for me to learn a little Chinese; moreover he arranged for me to teach both Indian and Chinese philosophy, which I have done ever since until I retired in the spring of 2018. Although I cannot keep up with a well-trained historian of any religion, I am literate in frontline research in those fields and can talk with scholars from most religious traditions. I'm recognized as a contemporary progressive Confucian philosopher (Neville 2000). I think it is possible for a theologian without walls to grow slowly from a position of naiveté and bias about religions to enough erudition to be conversant with thinkers from most traditions and to be relatively expert in those of personal interest.

\section{Systematic thinking}

In college I was taught that system in philosophy means the development of a group of connected categories in terms of which everything can be represented as a specification. Hegel, Peirce, and Whitehead were the model systematic thinkers, and I thought a lot about Whitehead's criteria for a philosophical system: consistency, coherence, adequacy, and applicability (Whitehead 1978). At my college, Yale, systematic thinking was encouraged, not discouraged, as would have happened at nearly any other college in those days. My senior thesis on interpretation and nature was my first attempt at a system.

Nevertheless, systems are based on core ideas, and my first core philosophical-theological idea came when I was in kindergarten. One of my classmates told me that God is a person. I checked with my father who said that, although Jesus was a person, God is more like light or electricity. I understood that idea at a five-year-old level and began working on it. My current theological naturalism is a more sophisticated version of my father's hypothesis. I never had a serious commitment to a personal God that I would have to get over in order to deal with Brahman or the Dao. About the time I was editing the church newsletter, one of my high school teachers said to me, "You know, Bob, that God is not in space or time." I understood immediately what he meant and agreed with it. I also immediately knew that understanding that idea was an unusual kind of thinking, to which I decided to dedicate my life. So my systematic theology of creation ex nibilo began in high school and became the topic of my PhD dissertation (1963), which was revised and published in 1968 as God the Creator (Neville 1968, 1992). That is a real systematic book, although not half as sophisticated as my recent systematic statement, Ultimates: Philosophical Theology Volume One (Neville 2013). ${ }^{2}$

The moral I draw about this part of my inquiry is that it is important to begin as soon as possible with systematic thinking and grow from naïve and brash to more sophisticated and intelligent. Do not wait until you have 
mastered everything that systems need and then try to put them together. People I've known who waited until old age to put things together in a systematic way simply did not develop the tastes and skill of system making. Good systems have multiple layers, and really good ones allow you to see through many layers and interconnections at once. So I think you have to start young, duck your head when critics cry "juvenile," and just make your system more complex and transparently simple.

\section{Comparative theology}

It is one thing to learn a lot about many religions and another to be able to compare them. Comparison usually begins by noting some at least surface similarities between the religious positions and then inquiring into just how similar and different they are. Progress in comparison, however, requires hard work identifying exactly the respects in which the comparison is being made. Comparison is always "with respect to something." The respects in which things can be compared are comparative categories, and they are astonishingly hard to develop. Often what looks like a similarity between two positions turns out to be thinking at cross purposes. Some years ago, for instance, some comparativists got excited about the similarities between sunyata in Buddhism and kenosis in Christianity. But upon examination, the similarities boiled down to the fact that both translate as "emptiness" in English: Buddhist sunyata is a metaphysical characteristic of things as experienced by enlightened people, and Christian kenosis is Christ's or a person's taking on a humble station. There was no respect in which they can be compared except the accident of translation into English. The question of gods is an interesting comparative one. But in what respects is it important to compare them? Whether religions believe in one, several, or thousands? How many are male, female, both, ungendered? Do the gods squabble in ways that affect humans? Are there divine hierarchies? What is at stake in these comparisons, all of which can be made? I suspect that continued reflection on gods gives rise to the comparative category of what is ultimate and how is it ultimate. Monotheisms identify the ultimate with one God, however differently that God might be understood among and within monotheisms. Polytheisms, even those with a top God in a hierarchy, do not consider the ultimate to be a god with intentional agency, but some deeper principle. Some religions like Buddhism, many forms of Hinduism, Confucianism, and Daoism in their early forms believed that the world is populated with many kinds of supernatural beings but that they were not ultimate at all. Confucianism and Daoism do not use many personalistic metaphors for ultimacy, but rather look to metaphors of spontaneous emergence. The important categories for comparing theological positions emerge only slowly with the process of learning and systematizing.

In my own experience, the categories that emerge as important for theological comparison, the respects in which it is important to compare religious 
positions, turn out to be the categories that are important for the system in philosophical theology. I think that there are five problematics that any seriously developed theological tradition must address: why there is something rather than nothing; how human choice determines not only what happens sometimes but also the character of the chooser; how to have a good self; how to relate to other people, institutions, and nature on their own terms; and what the meaning of life and existence is. These are extremely complicated problematics, and religions say many different things about them. But the problematics can be sorted through to develop important categories for comparative theology. Of course, the religious positions are often in wild disagreement. ${ }^{3}$ Theologians without walls need to make their own decisions about how to evaluate the positions compared.

The moral here is that the development of important comparative categories for theology is a long, evolving, and critical process. It is not that the theologian can first get categories for comparison and then work for years filling in how the theological positions compare. Rather, every comparative category is itself an hypothesis about the important respects in which to compare theological positions and should be kept vulnerable to correction throughout a comparative theologian's continuing inquiry. Start young and correct yourself.

\section{Programs of teaching}

I assume that most theologians without walls are teachers at the high school, undergraduate, or perhaps graduate levels. Some of us are retired from all that, and it is possible to be a serious theologian without walls without an academic career at all. Nevertheless, teaching helps one become a better theologian without walls. We all know that trying to explain something to students who do not know it makes you figure out just what you understand and what you do not.

I recommend that, to as great an extent as circumstances allow, we should teach courses about the three topics I have already mentioned, namely courses on different religions, courses on systematic theology aiming to say what you think is true, and courses in comparison where you lead students to understand both the nature of religion and what should be said about the most important theological topics. I have been fortunate that in my 57 years of teaching I have taught all three kinds of courses. Some people, of course, teach in religious schools where discussion of other religions is discouraged or forbidden. Some teach in schools where it is forbidden to say what you think is true on theological topics or admit to having a theological system. Some teach in places where there is no leisure for complicated discussions about the nature of comparison. But we should hope to teach the elements of theology without walls to as great an extent as possible.

Furthermore, we should teach these courses again and again, revising and improving them. Some changes in evolving curricula come from the 
changing nature of the students. Here I am advocating repetitive improvements based on what can be learned from teaching. In my 31 years at Boston University, I have been fortunate to teach a sequence of three advanced systematic courses nine times. Each sequence is a little different from the one before, and sometimes there are radical changes in the readings. Teaching this sequence again and again has led me to the publication of my threevolume philosophical theology based on some comparative erudition and aimed at an audience of anyone interested in the outcome of the inquiry. Teaching for many years is a great good fortune. I personally could have stopped grading papers 15 or 20 years ago, but the classroom is always fresh.

\section{Professional colleagues}

Another crucial part of the ongoing paideia for a theologian without walls is the cultivation of professional contacts. This is not likely to be done by having a whole department of theologians without walls, although Wesley Wildman advocates "academic theology" in colleges and universities as theology without walls (Wildman 2010). More likely is the possibility of developing collaborative friendships and close involvements with professional societies that are relevant to the many parts of theology without walls.

The professional societies can be of many sorts. For the sake of developing a philosophical system, I have been fortunate to be part of the Metaphysical Society of America from my graduate school days. It was founded by Paul Weiss, who was on my dissertation committee and who published my first professional philosophy paper in The Review of Metaphysics, which he founded and edited for many years. My own kind of philosophical heritage owes very much to American pragmatism, and I have long belonged to the Institute for American Religious and Philosophical Thought. More recently I have been involved with the Charles S. Peirce Society. For comparative work, my main interest has been in Confucianism, and I have been a multidecade member of the International Society for Chinese Philosophy. Theology without walls has flourished mainly in the American Academy of Religion to which I have belonged for most of my career. I have frequently given papers at these groups and have commented on others. They provide long-term communities of critics and encouragers. I have been involved with their administrations and have served as the president of each of them, engaging as a Confucian scholar-official.

Friends are perhaps the most important collaborators in developing a rich theology without walls over the long haul. Some friends come from special projects with which we can become involved. Others become the special friends that grow with you over the years. I myself have been greatly fortunate in friendships and am convinced that philosophical friendships, rather than the philosophical rush to refutation in which I was raised by analytic philosophers, are the proper venues for cultivating the openings into the depths of the soul. 


\section{Robert Cummings Neville}

\section{Publication}

As Boston's Mayor Curley said about voting, publish early and often. Do not wait until you have a perfectly polished piece of theology before you submit it for publication. Do not be afraid to grow in the press, publishing improved renditions of your ideas as they come to you. Find the publishing venues amenable to your work and pursue them. If the peer-review process elicits good criticisms, figure out where they are coming from and accept them selectively.

The more original your work, the less likely it is to be understood by reviewers and editors. When I first started out, my first book was rejected by a number of publishers before it was finally accepted after three years by the University of Chicago Press. During that dry period all of my articles were rejected as well. In frustration, I sent the rejected articles to Wilfrid Sellars, one of my graduate professors, and asked what to do. He wrote back that the philosophy I was doing was different from what was recognized in the assorted philosophical Balkans and that when my book was finally published, it would establish an audience for my work. That is pretty much what happened.

Theology without walls will not be recognized as legitimate theology by people who think theology is always based within some faith community. It will also not be recognized by most philosophers who do not like theology because they think it is always apologetic for some faith community. So we need to be patient in developing venues for the publication of theology without walls. Keep up the courage to sustain many rejections.

Two principal reasons exist for hope for the paideia and programs of theology without walls. First, theologies with walls reduce to sociological claims: this is what Thomists, Advaita Vedantins, and Confucians "believe" in their theologies. Most theologians cannot be satisfied with that and want their claims to be true, not just part of the grammar of a select group. Second, the world, especially colleges and universities, needs disciplined people to address the big theological questions: Why is there something rather than nothing? Why are human beings obligated and how? What is the nature of an ideal self, and how can that be achieved? How can we relate to others while respecting their perspectives? What is the meaning of life and existence? Many other first-order questions have rung the bells for centuries. Those questions cut across all religions and the assorted secularities. No one really trusts theologically walled-in answers to them. Colleges and universities need to make places for theology without walls, because those are the most basic and important questions.

I am a philosophical realist and believer that we get feedback from reality on ultimate theological questions, particularly, the feedback that says, "Why aren't you answering these questions?" Let's get to it. 


\section{Notes}

1 You will find an account of my childhood at www.robertcummingsneville.com, including embellishments of some of the stories I tell here.

2 That is part of the now larger system that includes Neville (2014) and Neville (2015).

3 See Neville $(2014,2015)$ to track some of these wild differences.

\section{References}

Neville, Robert C. 1968. God the Creator: On the Transcendence and Presence of God. 1st ed. Chicago: University of Chicago Press.

Neville, Robert C. 1992. God the Creator: On the Transcendence and Presence of God. rev. ed. Albany, NY: State University of New York Press.

Neville, Robert C. 2000. Boston Confucianism: Portable Tradition in the Late Modern World. Albany, NY: State University of New York Press. doi:10.1525/ nr.2004.7.3.105

Neville, Robert C. 2013. Ultimates: Philosophical Theology Volume One. Albany, NY: State University of New York Press.

Neville, Robert C. 2014. Existence: Philosophical Theology Volume Two. Albany, NY: State University of New York Press.

Neville, Robert C. 2015. Religion: Philosophical Theology Volume Three. Albany, NY: State University of New York Press.

Whitehead, Alfred N. 1978. Process and Reality: An Essay in Cosmology, Corrected Edition, edited by Donald W. Sherburne and David Ray Griffin. New York, NY: Macmillan/Free Press.

Wildman, Wesley J. 2010. “Afterword: Religious Philosophy in the Modern University." In Religious Philosophy as Multidisciplinary Comparative Inquiry: Envisioning a Future for the Philosophy of Religion, edited by Wesley J. Wildman, 307-318. Albany, NY: State University of New York Press. 